\title{
Arbuscular mycorrhizal fungal application to improve growth and tolerance of wheat (Triticum aestivum L.) plants grown in saline soil
}

\author{
Gamal M. Abdel-Fattah • Abdul-Wasea A. Asrar
}

Received: 9 March 2011 / Revised: 12 July 2011 / Accepted: 19 July 2011 / Published online: 10 August 2011

(C) The Author(s) 2011. This article is published with open access at Springerlink.com

\begin{abstract}
A pot experiment was conducted to examine the effects of three different arbuscular mycorrhizal fungi, Glomus mosseae, G. deserticola and Gigaspora gergaria, on growth and nutrition of wheat (Triticum aestivium L. cv. Henta) plants grown in saline soil. Under saline condition, mycorrhizal inoculation significantly increased growth responses, nutrient contents, acid and alkaline phosphatases, proline and total soluble protein of wheat plants compared to non-mycorrhizal ones. Those stimulations were related to the metabolic activity of the each mycorrhizal fungus. The localization of succinate dehydrogenase "SDH" (as a vital stain for the metabolically active fungus) in the arbuscular mycorrhizal fungi was variable. In general, mycorrhizal shoot plant tissues had significantly higher concentrations of $\mathrm{P}, \mathrm{N}, \mathrm{K}$ and $\mathrm{Mg}$ but lower $\mathrm{Na}$ concentration than those of non-mycorrhizal plants. In saline soil, growth and nutrition of wheat plants showed a high degree of dependency on mycorrhizal fungi (especially G. mosseae). The use of the nitroblue tetrazolium chloride method as a vital stain for SDH activity showed that all the structures of mycorrhizal infections in the wheat
\end{abstract}

Communicated by J. Zwiazek.

G. M. Abdel-Fattah $(\bowtie)$. A.-W. A. Asrar

Plant Production Department,

College of Food and Agriculture Sciences,

King Saud University, P.O. Box 2460,

Riyadh 11451, Saudi Arabia

e-mail: Abdelfattahvam@yahoo.com

A.-W. A. Asrar

e-mail: aasrar@ksu.edu.sa

G. M. Abdel-Fattah

Botany Department, Faculty of Science,

Mansoura University, Mansoura, Egypt plant estimated by the trypan blue staining (non-vital stain) were not metabolically active. Interestingly, the reduction in $\mathrm{Na}$ uptake along with associated increases in $\mathrm{P}, \mathrm{N}$ and $\mathrm{Mg}$ absorption and high proline, phosphatase activities and chlorophyll content in the mycorrhizal plants could be important for salt alleviation in plants growing in saline soils.

Keywords Arbuscular mycorrhizal fungi - Soil salinity · Minerals content · Mycorrhizal dependency · Proline .

Vital stain $\cdot$ Wheat

\section{Introduction}

Soil salinity is a worldwide dilemma, restricting plant growth and production especially in arid, semiarid and tropical regions through reducing nutrients uptake and increasing osmotic stress of plants (Apse et al. 1999; Abdel-Ghani 2009). Those regions are still increasing as a result of salt water irrigation and land degradation. Hence, increase in salt tolerance of crops and horticultural species is required to sustain the increases in food production in many regions of the world (Munns et al. 2006). The development of salt-tolerant crops or desalination of soil by leaching excessive salts is not sufficient to overcome this problem (Cantrell and Linderman 2001; Giri and Mukerji 2004). In recent years, the use of the biological application (mycorrhizal symbiosis) as a practical method to alleviate soil stresses like salinity on plant growth has received a greater attention (Abdel-Fattah et al. 1996; Daei et al. 2009; Wu et al. 2010).

In Saudi Arabia, wheat is one of the most important grain crops. Raising wheat through increasing the productivity per unit area as well as expanding the cultivated area 
in newly reclaimed lands is the major important national target. Increasing productivity per unit area, particularly in saline media, could be achieved by cultivating high yielded cultivars along with importing agronomical practices. As a result, arbuscular mycorrhizal plants are often more competitive and better tolerant to the environmental stresses than non-mycorrhizal plants (Abdel-Fattah et al. 2002; Paradi et al. 2002; Kumar et al. 2010; Asrar and ElHindi 2011)

Arbuscular mycorrhizal (AM) fungi as an integral part of terrestrial ecosystems, since they form symbiotic association with more than $90 \%$ of plant species (Harley and Smith 1983; Mankarios and Abdel-Fattah 1994). Many studies have reported the presence of the AM association in salt stress conditions (Pond et al. 1984; Ruiz-Lozano and Azcon 2000; Agwa and Abdel-Fattah 2001; Sheng et al. 2009; Kumar et al. 2010). In this concern, the introduction of arbuscular mycorrhizal fungi to sites with saline soil may improve plant tolerance and growth (Poss et al. 1985; Giri and Mukerji 2004; Al-Karaki 2006; Abo-Ghalia and Khalafallah 2008).

Under salt stress conditions, plant tolerance and production are complicated mechanisms. Arbuscular mycorrhizal fungi employ different mechanisms to enhance salt tolerance of host plants such as enhancing nutrient acquisition (P, N, Mg and Ca) (Azcon and Atrash 1997; Giri and Mukerji 2004; Sheng et al. 2009), inhibiting high uptake of $\mathrm{Na}$ and $\mathrm{Cl}$ and their transport to plant shoots (Daei et al. 2009), improving water uptake (Ruiz-Lozano and Azcon 2000), accumulating of proline and polyamines (Evelin et al. 2009; Ibrahim et al. 2011) and increasing some of enzymatic antioxidant defense system (SOD and CAT) (Wu et al. 2010). Other arbuscular mycorrhizal mechanisms may include an osmotic adjustment, which assist in maintaining the leaf turgor pressure, and effects on the photosynthesis, transpiration, stomatal conductance and water use efficiency (Juniper and Abbott 1993).

Measurements of enzyme activity have been used to judge the viability of arbuscular mycorrhizal fungi (Hamel et al. 1990; Abdel-Fattah 2001). Succinate dehydrogenase (SDH), which functions as an enzyme, can be used as a vital stain for metabolically active mycorrhizal fungi. It can be detected and examined directly in root tissue using chlorogenic assay (Kough et al. 1987). Alkaline phosphatase has been identified as an active enzyme in AM. It has been suggested that this enzyme may be involved in the processes of phosphorus acquisition of the mycorrhizal plants (Gianinazzi et al. 1992). Using this technique, the decreases in AM fungal activity with aging of the infection was not obvious with normal trypan blue staining (active and active fungal tissues) of the root tissues (Smith et al. 1990).

The present study was designed to study the efficiency of different arbuscular mycorrhizal (AM) fungi in enhancing plant growth, nutrient and mineral contents of wheat plants grown in saline soil. Histochemical staining of the succinate dehydrogenase (vital stain) activity as enzyme marker in AM fungal structures was investigated. Differences between this vital stain and non-vital trypan blue staining in mycorrhizal root tissues were determined. The possible utilization of this enzyme is to assess the AM fungal activity and its relation to reduce the adverse effects of the salinity stress on growth and nutrients of wheat plants was also studied.

\section{Materials and methods}

\section{Experimental design}

The experiment was carried out in a randomized complete block design. The experimental treatments consisted of four mycorrhizal treatments, G. mosseae (Nicol. and Gerd.) Gerdemann and Trappe, G. deserticola (Trappe and John) and Gigaspora gergaria (Becker and Hall) and non-AMF. Each of the four treatments was replicated ten times to give a total of 40 pots. Plants were grown for 3 months in a glasshouse at the experimental Research Station, Plant Production Department, College of Food and Agricultural Sciences, King Saud University, Saudi Arabia.

Inoculum preparation of arbuscular mycorrhizal species

The inoculum of arbuscular mycorrhizal species including G. mosseae, G. deserticola, and G. gergaria were originally isolated from saline soils of Al-Kassb region (185 km from Riyadh, Saudi Arabia) using the wet sieving and decanting technique (Gerdemann and Nicolson 1963), and then identified by the author (Abdel-Fattah 1991). The identified arbuscular mycorrhizal spores were left to multiply for 6 months on sudangrass plants (Sorghum halepense L.) using autoclaved $\left(121^{\circ} \mathrm{C}, 20 \mathrm{~min} ; 1.5\right.$ air pressure) sand soil, collected from the same site, in controlled environmental greenhouse conditions $\left(25^{\circ} \mathrm{C}\right.$ day/ $20^{\circ} \mathrm{C}$ night temperatures, $65 \%$ relative humidity, $16 / 8 \mathrm{~h}$ light/dark period cycle with a photosynthetic photon flux density of $500-700 \mu \mathrm{mol} \mathrm{m}{ }^{-2} \mathrm{~s}^{-1}$ ) at College of Sciences, King Saud University. Plants were irrigated with tap water as needed and the nutrient solutions (Hoagland without phosphorus) of plants were supplied. A mixture of plant roots and sand soil which contained spores was used as mycorrhizal inoculum.

Soil physical and chemical analysis

Before planting, combined soil samples up to a $20-\mathrm{cm}$ depth were collected from Al-Kassb saline area, and their 
Table 1 The physical and chemical properties of soil used throughout this study

\begin{tabular}{ll}
\hline Sand (\%) & 69 \\
Silt (\%) & 21 \\
Clay (\%) & 10 \\
Soil texture & Sand \\
pH & 7.79 \\
E.C $\left(\mathrm{ds} \mathrm{m}^{-1}\right)$ & 6.11 \\
Organic carbon $(\%)$ & 0.23 \\
$\mathrm{~N}\left(\mathrm{mg} \mathrm{kg}^{-1}\right)$ & 65.0 \\
$\mathrm{P}\left(\mathrm{mg} \mathrm{kg}^{-1}\right)$ & 10.5 \\
$\mathrm{~K}\left(\mathrm{mg} \mathrm{kg}^{-1}\right)$ & 125 \\
$\mathrm{Na}\left(\mathrm{mg} \mathrm{kg}^{-1}\right)$ & 860 \\
$\mathrm{Mg}\left(\mathrm{mg} \mathrm{kg}^{-1}\right)$ & 118 \\
$\mathrm{Ca}\left(\mathrm{mg} \mathrm{kg}^{-1}\right)$ & 445 \\
\hline
\end{tabular}

main chemical and physical properties were determined in soil-water extract (1:5 w/v) according to Allen (1989). The total N (Kjeldah method, Nelson and Sommers 1973), and the available concentrations of $\mathrm{P}$ (Olsen et al. 1954), K, Ca, $\mathrm{Na}$ and $\mathrm{Mg}$ (flam photometer method, emission spectrophotometry, Knudsen et al. 1982) were determined (Table 1).

Plant and growth conditions

Grains of wheat (Triticum aestivum L. cv. Henta, provided from the Ministry of Agriculture, Riyadh, Saudi Arabia) were surface sterilized in $7 \%$ sodium hypochlorite for $10 \mathrm{~min}$, subsequently rinsed with sterilized distilled water and left to germinate for $48 \mathrm{~h}$ on moistened sterilized filter paper in dark at $25^{\circ} \mathrm{C}$. Uniform germinated seedlings were planted (four plants/pot) in sterilized plastic pots $(18 \mathrm{~cm}$ in depth and $20 \mathrm{~cm}$ in diameter) containing $3.5 \mathrm{~kg}$ of autoclaved $\left(121^{\circ} \mathrm{C}, 20 \mathrm{~min}\right.$; 1.5 air pressure for 3 separate time) sandy saline soil. For mycorrhizal inoculation, each pot was inoculated with $3 \mathrm{~g}$ of soil (approx. 80 spores/g soil) and $1 \mathrm{~g}$ of chopped fresh sudangrass roots infected $(M=78 \%)$ by stock culture of each corresponding mycorrhizal fungus. The inoculum was placed $3 \mathrm{~cm}$ below the germinated wheat grains at sowing to produce mycorrhizal plants. The un-inoculated pots (non-AMF) received filter leaching (Whatman 1) from infected roots and sterilized equal amount of soil inoculum to provide the associated microorganisms other than mycorrhizal propagules. Plants were grown in a glasshouse of the Plant Production Department, College of Food and Agricultural Science, under natural day/night conditions (minimum/maximum temperature, relative humidity and day length $\left(25 / 17^{\circ} \mathrm{C}\right.$, $55 / 65 \%$ and 10/14 h; respectively). All plants were regularly irrigated as needed with tap water to maintain soil moisture near field capacity. Four weeks after planting, all plants received $32 \mathrm{mg}$ sulfur (as potassium sulfate) $\operatorname{pot}^{-1}$ as a nutrient solution. Harvesting (ten plants per each treatment) was carried out after 8 weeks (at tillering stage) and 12 weeks (at anthesis stage) after planting.

Measurements

\section{Growth parameters}

At each harvest, shoot height and leaf number per plant were recorded. Dry $\left(70^{\circ} \mathrm{C}\right.$ for $\left.48 \mathrm{~h}\right)$ weights of shoots and roots, and root/shoot ratio were determined. The leaf area was estimated according to the following equation $\left\{L_{\mathrm{cm}} \times W_{\mathrm{cm}} \times 0.785\right\}$ where $L$ is the length of the leaf and $W$ is the maximum width of the leaf (Shih and Synder 1984). Mycorrhizal dependency was calculated as a percentage increase in dry weight of mycorrhizal plants over dry weight of non-mycorrhizal plants (Graham and Syvertsen 1985).

\section{Estimation of photosynthetic pigments}

Photosynthetic pigments (chlorophyll $a$, chlorophyll $b$ and carotenoids) in leaves were determined by an extracting method using dimethyl sulphoxide according to Harborne technique (Harborne 1984) using the equation of Arnon (1949).

\section{Mineral analysis}

Oven-dried plant matter was grounded and sieved through a $0.5-\mathrm{mm}$ sieve. A known weight of the grounded material was digested in a digestion flask containing a triple acid mixture $\left(\mathrm{HNO}_{3}: \mathrm{H}_{2} \mathrm{SO}_{4}: 60 \% \mathrm{HCl}_{4}\right.$, with a ratio of $10: 1: 4$, respectively) to analyze of $\mathrm{P}, \mathrm{K}, \mathrm{Mg}, \mathrm{Ca}$ and $\mathrm{Na}$. Phosphorus $(\mathrm{P})$ was extracted by nitric-perchloric acid digestion and measured using the Vanado-molybdophosphoric colorimetric method (Jackson 1973). Potassium (K) and sodium (Na) were assayed using a flame spectrophotometer, while calcium $(\mathrm{Ca})$ and magnesium $(\mathrm{Mg})$ were determined using atomic absorption according to the method of Allen (1989). Total N was determined by Kjeldahl method (Nelson and Sommers 1973).

\section{Detection the levels of mycorrhizal colonization}

Immediately after harvesting, a part of the root system was washed carefully in ice-cold water (to remove the adhering soil particles at $4^{\circ} \mathrm{C}$ ) and used for histochemical estimation of fungal succinate dehydrogenase (SDH) activity in the infections (as explained below) and for the total mycorrhizal infection (TB) after clearing the roots in $10 \% \mathrm{KOH}$ and staining with trypan blue in lactophenol (Phillips and Hayman 1970). The intensity of infection (M\%) and 
arbuscular development of the infected regions of the roots $(A \%)$ were detected in root samples stained for the total (tryban blue, TB) and for the living (SDH) fungal infection by the method of Trouvelot et al. (1986).

\section{Histochemical staining of succinate dehydrogenase activity (vital stain)}

SDH activity was determined histochemically by the depositing of purple formozan following reduction of the nitroblue tetrazolium (NBT) in the presence of succinate (Kough et al. 1987). Roots were cut into $0.5 \mathrm{~cm}$ lengths and incubated in a room temperature in $0.05 \mathrm{M}$ Tris buffer solution (pH 7.4) containing $0.5 \mathrm{mM} \mathrm{MgCl}_{2}, 1 \mathrm{mg} \mathrm{ml}^{-1}$ nitro blue tetrazolium salt and $0.25 \mathrm{M}$ sodium succinate. The stained fungi were cleared in $20 \%$ (w/v) boiling aqueous chloral hydrate for 10-15 min after which the color was stable. The complete reduction in the tetrazolium salt yields a dark blue/purple formozan, and the partial reduction results in a red/formozan. Thus, both extent of formozan deposition and its color give an indication for the activity of SDH in the fungal mitochondria.

\section{Quantitative analysis of total soluble protein and phosphatase activities}

Immediately after harvesting, part of the root system was washed carefully in ice-cold water to remove any adhering soil particles at $4^{\circ} \mathrm{C}$. A known root fresh weight was macerated in $0.1 \mathrm{M}$ borate buffer $(\mathrm{pH} 8.5)$, and the homogenate was centrifuged at $4,200 \mathrm{~g}$ for $10 \mathrm{~min}$. Acid and alkaline phosphatase activities were measured quantitatively in the supernatant using the technique of Gianinazzi-Pearson and Gianinazzi (1976). Enzyme activity was expressed as $\mathrm{mU} \mathrm{ml}^{-1}$ of root extract, where $\mathrm{U}$,
1 enzyme unit, is that enzyme activity which transforms $1 \mu \mathrm{mol}$ of substrate in $1 \mathrm{~min}$. The total soluble protein in root extract was determined by the method of Bradford (1976).

\section{Determination of proline}

Proline was extracted by homogenization of a known leaf dry weight in $3 \%$ aqueous sulphosalicylic acid, and determined by the spectrophotometeric method adopted by Sadasivam and Manickam (1996), using pure proline (Merck) as a standard.

\section{Statistical analysis}

Data were statistically analyzed using one-way analysis of variance, and the means were separated by Duncan's multiple range test by the least significant difference (LSD, $P \leq 0.05$ ) method using Costat software (Cohort, Berkeley, calif.).

\section{Results}

Plant growth

In general, leaf area, shoot and root dry masses, number of leaves and shoot height of mycorrhizal wheat plants were significantly higher than those of non-mycorrhizal plants at tillering and anthesis stages of the plants (Table 2). The magnitude of the mycorrhizal response in these parameters varied with the three endophytes used. Such increases in growth parameters of wheat plants due to mycorrhizal colonization were directly proportional to the level of each mycorrhizal infection. Out of these fungi, G. mosseae was

Table 2 Effect of different arbuscular mycorrhizal fungi (AMF) on growth responses and leaf area of wheat plants grown in saline soil

\begin{tabular}{|c|c|c|c|c|c|c|c|}
\hline $\begin{array}{l}\text { Weeks after } \\
\text { planting }\end{array}$ & $\begin{array}{l}\text { AMF } \\
\text { treatments }\end{array}$ & $\begin{array}{l}\text { Shoot dry weight } \\
\text { (g/plant) }\end{array}$ & $\begin{array}{l}\text { Root dry weight } \\
\text { (g/plant) }\end{array}$ & $\begin{array}{l}\text { Root/shoot } \\
\text { ratio }\end{array}$ & $\begin{array}{l}\text { Shoot height } \\
\text { (cm/plant) }\end{array}$ & $\begin{array}{l}\text { No. of leaves/ } \\
\text { plant }\end{array}$ & $\begin{array}{l}\text { Leaf area } \\
\left(\mathrm{cm}^{2}\right)\end{array}$ \\
\hline \multirow[t]{5}{*}{8} & Non-AMF & $1.48 \mathrm{c}^{*}$ & $0.52 \mathrm{c}$ & $0.351 \mathrm{a}$ & $31.5 \mathrm{c}$ & $4.3 \mathrm{~b}$ & $12.5 \mathrm{c}$ \\
\hline & $\mathrm{Gm}$ & $2.09 \mathrm{a}$ & $0.71 \mathrm{a}$ & $0.340 \mathrm{a}$ & $42.0 \mathrm{a}$ & $5.0 \mathrm{a}$ & $15.4 \mathrm{a}$ \\
\hline & $\mathrm{Gd}$ & $1.88 \mathrm{~b}$ & $0.61 \mathrm{~b}$ & $0.324 \mathrm{a}$ & $39.8 \mathrm{ab}$ & $4.9 \mathrm{a}$ & $13.4 \mathrm{~b}$ \\
\hline & Gig & $1.55 \mathrm{c}$ & $0.55 \mathrm{c}$ & $0.355 \mathrm{a}$ & $35.1 \mathrm{c}$ & $4.3 \mathrm{~b}$ & $12.6 \mathrm{c}$ \\
\hline & $\operatorname{LSD}(5 \%)$ & 0.12 & 0.04 & 0.03 & 4.2 & 0.42 & 1.2 \\
\hline \multirow[t]{5}{*}{12} & Non-AMF & $3.24 \mathrm{~d}$ & $1.42 \mathrm{c}$ & $0.438 \mathrm{a}$ & $45.8 \mathrm{~b}$ & $6.1 \mathrm{~b}$ & $19.8 \mathrm{~b}$ \\
\hline & $\mathrm{Gm}$ & $5.95 \mathrm{a}$ & $2.01 \mathrm{a}$ & $0.337 \mathrm{c}$ & $56.4 \mathrm{a}$ & $7.3 \mathrm{a}$ & $24.3 \mathrm{a}$ \\
\hline & Gd & $4.10 \mathrm{~b}$ & $1.61 \mathrm{~b}$ & $0.390 \mathrm{~b}$ & $50.6 \mathrm{ab}$ & $6.9 \mathrm{a}$ & $22.7 \mathrm{ab}$ \\
\hline & Gig & $3.69 \mathrm{c}$ & $1.50 \mathrm{c}$ & $0.393 \mathrm{~b}$ & $48.3 \mathrm{~b}$ & $6.0 \mathrm{~b}$ & $20.2 \mathrm{~b}$ \\
\hline & $\operatorname{LSD}(5 \%)$ & 0.16 & 0.09 & 0.04 & 5.1 & 0.65 & 2.3 \\
\hline
\end{tabular}

Non-AMF Non-mycorrhizal, Gm Glomus mosseae, Gd Glomus deserticola, Gig Gigaspora gergaria

* Values in each column of each harvest followed by the same letter(s) are not significantly different at $P \leq 0.05$ (Duncan's multiple range test) 
the most efficient for its ability to increase plant growth. On the other hand, there were no significant differences in dry matter, number of leaves and leaf area between mycorrhizal plants inoculated with G. gergaria and nonmycorrhizal plants. No significant differences in root/shoot dry mass yield ratio were observed between mycorrhizal and non-mycorrhizal wheat plants grown in saline soil, particularly after 8 weeks of planting.

\section{Photosynthetic pigments}

In most cases, the contents of the photosynthetic pigments (chlorophyll $a$, chlorophyll $b$ and carotenoids) in leaves of mycorrhizal plants were significantly greater than those of non-mycorrhizal plants at two stages of plant growth (Table 3). Such stimulations in these contents were related to the degree of each mycorrhizal infection. Nevertheless, no significant differences were observed in the total photosynthetic pigment contents between wheat plants colonized with G. gergaria and non-mycorrhizal control plants at all growth stages. Data in Table 2 show that the total photosynthetic pigments were highly decreased with aging of the plant grown in saline soil. However, the chlorophyll contents in the mycorrhizal plants, particularly in case of G. mosseae, were significantly greater than those in the non-mycorrhizal plants.

Active (SDH) and inactive (TB) mycorrhizal root infection

Both the intensity of the mycorrhizal infection $(M \%)$ and the arbuscule frequency $(A \%)$ in roots of wheat plants revealed by two staining procedures (SDH and $\mathrm{TB}$ ) showed variation among the fungal treatments (Table 4).
G. mosseae infected most highly among the three endophyte fungi was used in this study, followed by $G$. deserticola. However, the infection of G. gergaria spread slowly at all growth stages of the plants.

In saline soil, the levels of mycorrhizal colonization ( $M \%$ and $A \%)$ in roots estimated by TB (non-vital stain) continued to increase with age, but the intensity of the infection and arbuscule frequency showing SDH activity (vital stain) was significantly decreased. The amount of arbuscules $(A \%)$ in the infected regions of the root stained for SDH activity was significantly lower than the total infection stained with TB at two stages of the plant growth. Yet, the reduction rate was pronounced at anthesis stage of the plant growth. No mycorrhizal colonization was observed in non-mycorrhizal wheat plants.

Phosphatase activities and total soluble protein

In all treatments, soluble acid phosphatase activity was much higher than alkaline phosphatase, and these activities were highly affected by mycorrhizal inoculation at two stages of the plant growth (Table 5). In saline soil, total soluble protein and soluble phosphatase activities in root extracts were significantly higher in mycorrhizal wheat plants than in non-mycorrhizal ones. Such increases in activities in response to the mycorrhizal fungi were related to the degree of each of those mycorrhizal infections. On the other hand, no significant differences were observed in alkaline phosphatase activity between the root extracts of wheat plants colonized by G. gergaria and those nonmycorrhizal plants at tillering stage of plant growth.

Total soluble protein and phosphatase activities of the mycorrhizal and non-mycorrhizal root extracts of wheat plants were greatly reduced with increasing plant growth.

Table 3 Effect of the different arbuscular mycorrhizal fungi (AMF) on the content of the photosynthetic pigments ( $\mu \mathrm{g} \mathrm{g}{ }^{-1}$ fresh wt.) in leaves of wheat plants grown in saline soil

\begin{tabular}{|c|c|c|c|c|c|}
\hline $\begin{array}{l}\text { Weeks after } \\
\text { planting }\end{array}$ & AMF treatments & Chlorphyll " $a$ " & Chlorophyll " $b$ " & Carotenoids & $\begin{array}{l}\text { Total } \\
\text { pigments }\end{array}$ \\
\hline \multirow[t]{5}{*}{8} & Non-AMF & $1,016 \mathrm{c}^{*}$ & $780 \mathrm{c}$ & $159 \mathrm{c}$ & $1,955 \mathrm{c}$ \\
\hline & $\mathrm{Gm}$ & $1,902 \mathrm{a}$ & $1,322 \mathrm{a}$ & $324 \mathrm{a}$ & 3,548 a \\
\hline & $\mathrm{Gd}$ & $1,761 \mathrm{~b}$ & $1,109 \mathrm{~b}$ & $212 b$ & $3,082 \mathrm{~b}$ \\
\hline & Gig & $1,175 \mathrm{c}$ & $849 \mathrm{c}$ & $192 \mathrm{c}$ & $2,216 \mathrm{c}$ \\
\hline & $\operatorname{LSD}(5 \%)$ & 205 & 122 & 45 & 320 \\
\hline \multirow[t]{5}{*}{12} & Non-AMF & $883 \mathrm{~b}$ & $240 \mathrm{~b}$ & $120 \mathrm{c}$ & $1,243 \mathrm{~b}$ \\
\hline & $\mathrm{Gm}$ & $997 \mathrm{a}$ & $320 \mathrm{a}$ & $201 \mathrm{a}$ & $1,518 \mathrm{a}$ \\
\hline & $\mathrm{Gd}$ & $900 \mathrm{~b}$ & $301 \mathrm{ab}$ & $160 \mathrm{~b}$ & $1,361 \mathrm{~b}$ \\
\hline & Gig & $894 \mathrm{~b}$ & $290 \mathrm{c}$ & $121 \mathrm{c}$ & $1,305 \mathrm{~b}$ \\
\hline & $\operatorname{LSD}(5 \%)$ & 89 & 21 & 12 & 120 \\
\hline
\end{tabular}

Non-AMF Non-mycorrhizal, Gm Glomus mosseae, Gd Glomus deserticola, Gig Gigaspora gergaria

* Values in each column of each harvest followed by the same letter(s) are not significantly different at $P \leq 0.05$ (Duncan's multiple range test) 
Table 4 The intensity of root colonization $(M \%)$ and the arbuscular frequency $(A \%)$ of mycorrhizal infection as estimated by non-vital trypan blue (TB) and succinate dehydrogenase (SDH) stained in roots of wheat plants grown in saline soil

\begin{tabular}{|c|c|c|c|c|c|}
\hline \multirow{3}{*}{$\begin{array}{l}\text { Weeks after } \\
\text { planting }\end{array}$} & \multirow[t]{3}{*}{ AMF treatments } & \multicolumn{4}{|c|}{ Stain type } \\
\hline & & \multicolumn{2}{|l|}{$\mathrm{TB}$} & \multicolumn{2}{|l|}{$\mathrm{SDH}$} \\
\hline & & $M \%$ & $A \%$ & $M \%$ & $A \%$ \\
\hline \multirow[t]{5}{*}{8} & Non-AMF & $0.0 \mathrm{c}^{*}$ & $0.0 \mathrm{c}$ & $0.0 \mathrm{~d}$ & $0.0 \mathrm{~d}$ \\
\hline & $\mathrm{Gm}$ & $51.6 \mathrm{a}$ & $38.9 \mathrm{a}$ & $45.9 \mathrm{a}$ & $33.1 \mathrm{a}$ \\
\hline & Gd & $45.3 \mathrm{a}$ & $34.0 \mathrm{a}$ & $34.2 \mathrm{~b}$ & $23.2 \mathrm{~b}$ \\
\hline & Gig & $31.5 \mathrm{~b}$ & $29.0 \mathrm{~b}$ & $22.0 \mathrm{c}$ & $13.1 \mathrm{c}$ \\
\hline & $\operatorname{LSD}(5 \%)$ & 14.1 & 11.9 & 10.0 & 5.3 \\
\hline \multirow[t]{5}{*}{12} & Non-AMF & $0.0 \mathrm{~d}$ & $0.0 \mathrm{~d}$ & $0.0 \mathrm{~d}$ & $0.0 \mathrm{~d}$ \\
\hline & $\mathrm{Gm}$ & $79.4 \mathrm{a}$ & $65.0 \mathrm{a}$ & $36.6 \mathrm{a}$ & $28.2 \mathrm{a}$ \\
\hline & $\mathrm{Gd}$ & $66.0 \mathrm{~b}$ & $53.0 \mathrm{~b}$ & $25.2 \mathrm{~b}$ & $12.0 \mathrm{~b}$ \\
\hline & Gig & $40.9 \mathrm{c}$ & $38.0 \mathrm{c}$ & $12.9 \mathrm{c}$ & $6.4 \mathrm{c}$ \\
\hline & LSD (5\%) & 14.0 & 11.0 & 8.1 & 5.1 \\
\hline
\end{tabular}

Non-AMF Non-mycorrhizal, Gm Glomus mosseae, Gd Glomus deserticola, Gig Gigaspora gergaria

* Values in each column of each harvest followed by the same letter(s) are not significantly different at $P \leq 0.05$ (Duncan's multiple range test)

Table 5 Effect of the different mycorrhizal fungi on quantitative changes in soluble acid, alkaline phosphatase activities and protein content $\left(\mu \mathrm{g} \mathrm{g}^{-1}\right.$ fresh wt.) in root tissues of wheat plants grown in saline soil

\begin{tabular}{|c|c|c|c|c|}
\hline $\begin{array}{l}\text { Weeks after } \\
\text { planting }\end{array}$ & Treatments & $\begin{array}{l}\text { Acid phosphatase } \\
\text { activity }\end{array}$ & $\begin{array}{l}\text { Alkaline phosphatase } \\
\text { activity }\end{array}$ & Protein \\
\hline \multirow[t]{5}{*}{8} & Non-AMF & $840 \mathrm{c}^{*}$ & $315 \mathrm{c}$ & $751 \mathrm{~d}$ \\
\hline & $\mathrm{Gm}$ & $1,355 \mathrm{a}$ & 394 a & $1,283 \mathrm{a}$ \\
\hline & $\mathrm{Gd}$ & $1,244 \mathrm{ab}$ & $350 \mathrm{~b}$ & $1,140 \mathrm{~b}$ \\
\hline & Gig & $1,020 \mathrm{~b}$ & $320 \mathrm{c}$ & $844 \mathrm{c}$ \\
\hline & $\operatorname{LSD}(5 \%)$ & 120 & 25 & 85 \\
\hline \multirow[t]{5}{*}{10} & Non-AMF & $625 \mathrm{~d}$ & $220 \mathrm{~d}$ & $660 \mathrm{~b}$ \\
\hline & $\mathrm{Gm}$ & $830 \mathrm{a}$ & $295 \mathrm{a}$ & $770 \mathrm{a}$ \\
\hline & $\mathrm{Gd}$ & $740 \mathrm{~b}$ & $270 \mathrm{~b}$ & $671 \mathrm{~b}$ \\
\hline & Gig & $680 \mathrm{c}$ & $245 \mathrm{c}$ & $640 \mathrm{~b}$ \\
\hline & LSD (5\%) & 55 & 22 & 35 \\
\hline
\end{tabular}

Enzyme activity was expressed as $\mathrm{mU} / \mathrm{ml}$ of root extract, where $\mathrm{U}$, is an enzyme unit, which is the enzyme activity that transforms $1 \mu \mathrm{mol}$ of substrate in $1 \mathrm{~min}$

Non-AMF Non-mycorrhizal, Gm Glomus mosseae, Gd Glomus deserticola, Gig Gigaspora gergaria

* Values in each column of each harvest followed by the same letter(s) are not significantly different at $P \leq 0.05$ (Duncan's multiple range test)

The rate of reduction in the mycorrhizal treatments was related to the degree of the active mycorrhizal infection revealed by SDH stain.

\section{Proline content}

In general, proline content in leaves of mycorrhizal wheat plants was significantly higher than that in non-mycorrhizal plants grown in saline soil (Fig. 1), and the effect was more pronounced at anthesis stage of the plant growth. Such increases in proline content were linked to the degree of the mycorrhizal infection. Among all the studied fungi,
$G$. mosseae and $G$. deserticola were the most efficient for their ability to improve proline content. No significant differences in proline content were observed between $G$. gergaria inoculated plants and the non-mycorrhizal plants at two stages of the plant growth.

Nutrients and minerals content

In saline soil, phosphorus, nitrogen, potassium, calcium and magnesium contents in shoot tissues of the mycorrhizal plants, in most cases, were significantly greater than those in the equivalent non-mycorrhizal plants at all harvests 


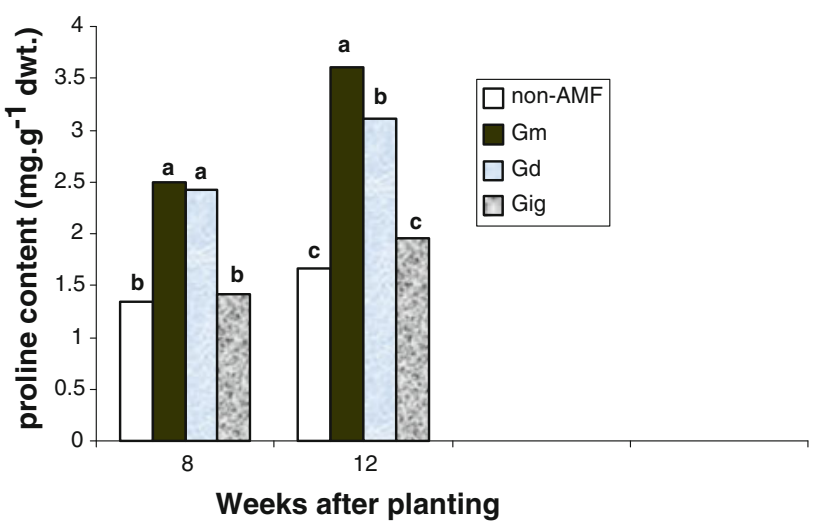

Fig. 1 Effect of the different arbuscular mycorrhizal fungi (AMF) on proline content ( $\mathrm{mg} \mathrm{g}^{-1}$ dry wt.) in leaves of wheat plants grown in saline soil. Bars of each harvest with the same letter are not significantly different $(P \leq 0.05)$ by Duncan's multiple range test. Non-AMF Non-mycorrhizal, Gm Glomus mosseae, Gd Glomus deserticola, Gig Gigaspora gergaria

(Table 6). Such increases in nutrient contents in response to the mycorrhizal effects were highly associated, respectively, with the level of each mycorrhizal infection. Out of these fungi, G. mosseae and G. deserticola were the most efficient for their abilities to increase nutrient and mineral contents of wheat plants at two stages of the plant growth.

AM-inoculated plants exhibited reduction in $\mathrm{Na}$ concentration in shoot tissues compared to non-inoculated control plants (Table 6). The rate of reduction in Na content was related to the infection of each mycorrhizal fungus. G. mosseae inoculated wheat plants had sodium concentration lower than non-mycorrhizal ones by 50 and $40 \%$ at tillering and anthesis stages of plant growth, respectively.

Mycorrhizal dependency and active arbuscular infection

Table 7 indicates that there was a close link between amount of metabolic activity in arbuscular infection and the mycorrhizal dependency in wheat plants grown in saline soil. As the active arbuscule frequency stained for SDH increased, the percentages of the mycorrhizal dependency on plant growth, nutrient content $(\mathrm{P})$ and total chlorophyll $(a+b)$ contents were highly stimulated.

Among all the different AM species tested in this study, the G. mosseae has the greatest effects on plant growth and other physiological parameters. Wheat plants at tillering stage showed 109, 106 and $79.5 \%$ dependency on G. mosseae under salt stress for their dry mass, $\mathrm{P}$ content and total chlorophyll content, respectively. In the mean time, wheat plants had a considerable degree of dependence on G. deserticola compared to G. gergaria fungus at two stages of the plant growth.

\section{Discussion}

Salinity is one of the main problems that affects agricultural practices in most regions of the kingdom of Saudi Arabia. Soil salinity decreases the crop yield by increasing the osmotic stress, nutrient deficiency and affecting various physiological and biochemical mechanisms associated with plant growth and development (Sairam et al. 2002). In saline soil, colonization of wheat plants by different species of arbuscular mycorrhizal fungi significantly increased growth responses, acid and alkaline phosphatases, proline and total soluble protein compared to those of nonmycorrhizal plants. The magnitude of the growth response varied among the fungal species, and it was directly proportional to the levels of active infection of each mycorrhizal fungus. G. mosseae was the most efficient (out of the three mycorrhizal fungi used in this experiment) for its ability to increase plant growth, metabolic activity, and nutrient contents and level of active arbuscular formation. The most prominent contribution of these fungi to plant growth is mainly due to the uptake of phosphorus, and other elements by extraradical mycorrhizal hyphae, and transferring them to the root tissues (Al-karaki et al. 2001; Giri and Mukerji 2004; Wu et al. 2010). This result supports the previous finding which indicated that AM-inoculated wheat plants grow better than non-inoculated plants under salt stress conditions (Daei et al. 2009; Ibrahim et al. 2011).

Soil salinity significantly reduces the absorption of the mineral nutrients, mainly $\mathrm{P}, \mathrm{N}$ and $\mathrm{K}$ in non-mycorrhizal plants. AM-inoculated plants had significantly greater concentrations of P (Azcon and Atrash 1997; Roychoudhury et al. 2010), N (Founoune et al. 2002) and K than those of non-mycorrhizal plants (Table 4). These findings allow us to deduce that the increased salinity tolerance in mycorrhizal plants is based on $\mathrm{P}$ nutrition and other minerals (Azcon and Atrash 1997). In saline soil, higher absorption of $\mathrm{P}$ in AM-inoculated plants may improve growth rate, salt tolerance and suppress the adverse effect of the salinity stress (Poss et al. 1985; Kumar et al. 2010). In addition, Duke et al. (1986) concluded that in addition to $\mathrm{P}$ uptake enhancement, there were some other mechanisms such as induction of the osmotic materials that led to osmotic adjustment and improved salt tolerance in mycorrhizal plants. However, Marschner (1995) demonstrated that balanced nutrition increased the salt tolerance capacity of plants.

It is evident from the present study that AM plants exhibited low $\mathrm{Na}^{+}$and increased $\mathrm{K}^{+}$and $\mathrm{Ca}^{2+}$ contents in shoot tissues compared to non-mycorrhizal plants. Such reduction in $\mathrm{Na}^{+}$was related to the viability (estimated by vital SDH stain) of each mycorrhizal fungus. It appears that the role of the mycorrhizal fungi in alleviating salt stress is 
Table 6 Phosphorus, nitrogen, potassium, calcium, magnesium and sodium contents ( $\mathrm{mg} \mathrm{g}^{-1}$ dry wt.) in shoots of wheat plants colonized with the different arbuscular mycorrhizal fungi and grown in saline soil

\begin{tabular}{|c|c|c|c|c|c|c|}
\hline \multirow{2}{*}{$\begin{array}{l}\text { Weeks after } \\
\text { planting }\end{array}$} & \multirow{2}{*}{$\begin{array}{l}\text { Nutrients and } \\
\text { minerals content }\end{array}$} & \multicolumn{5}{|c|}{ AM fungal species } \\
\hline & & Non-AMF & $\mathrm{Gm}$ & Gd & Gig & $\operatorname{LSD}(5 \%)$ \\
\hline \multirow[t]{6}{*}{8} & $\mathrm{P}$ & $1.15 \mathrm{c}^{*}$ & $2.38 \mathrm{a}$ & $1.88 \mathrm{~b}$ & $1.36 \mathrm{c}$ & 0.40 \\
\hline & $\mathrm{N}$ & $9.8 \mathrm{bc}$ & $18.8 \mathrm{a}$ & $14.1 \mathrm{ab}$ & $11.7 \mathrm{~b}$ & 4.7 \\
\hline & $\mathrm{K}$ & $12.4 \mathrm{c}$ & $29.7 \mathrm{a}$ & $20.4 \mathrm{~b}$ & $13.8 \mathrm{c}$ & 3.1 \\
\hline & $\mathrm{Ca}$ & $3.2 \mathrm{c}$ & $9.1 \mathrm{a}$ & $5.7 \mathrm{~b}$ & $3.5 \mathrm{c}$ & 1.4 \\
\hline & $\mathrm{Mg}$ & $1.3 \mathrm{c}$ & $3.6 \mathrm{a}$ & $2.2 \mathrm{~b}$ & $1.4 \mathrm{c}$ & 0.7 \\
\hline & $\mathrm{Na}$ & $2.180 \mathrm{a}$ & $1.202 \mathrm{c}$ & $1.654 \mathrm{~b}$ & $1.989 \mathrm{a}$ & 0.25 \\
\hline \multirow[t]{6}{*}{12} & $\mathrm{P}$ & $4.63 \mathrm{c}$ & $7.13 \mathrm{a}$ & $6.51 \mathrm{~b}$ & $4.90 \mathrm{c}$ & 0.95 \\
\hline & $\mathrm{N}$ & $20.6 \mathrm{c}$ & $70.5 \mathrm{a}$ & $53.2 \mathrm{~b}$ & $25.1 \mathrm{c}$ & 11.7 \\
\hline & K & $20.5 \mathrm{c}$ & $62.0 \mathrm{a}$ & $38.2 \mathrm{~b}$ & $23.5 \mathrm{c}$ & 6.8 \\
\hline & $\mathrm{Ca}$ & $5.1 \mathrm{~d}$ & $49.2 \mathrm{a}$ & $15.2 \mathrm{~b}$ & $10.1 \mathrm{c}$ & 4.5 \\
\hline & $\mathrm{Mg}$ & $2.7 \mathrm{c}$ & $30.1 \mathrm{a}$ & $8.5 \mathrm{~b}$ & $4.9 \mathrm{c}$ & 3.0 \\
\hline & $\mathrm{Na}$ & $3.89 \mathrm{a}$ & $2.30 \mathrm{c}$ & $3.5 \mathrm{~b}$ & $3.91 \mathrm{a}$ & 0.21 \\
\hline
\end{tabular}

Non-AMF Non-mycorrhizal, Gm Glomus mosseae, Gd Glomus deserticola, Gig Gigaspora gergaria

* Values in each column of each harvest followed by the same letter(s) are not significantly different at $P \leq 0.05$ (Duncan's multiple range test)

Table 7 The mycorrhizal dependency (MD) and proportion of active arbuscular colonization with SDH activity of wheat plants grown in saline soil

\begin{tabular}{|c|c|c|c|c|c|}
\hline \multirow{3}{*}{$\begin{array}{l}\text { Weeks after } \\
\text { planting }\end{array}$} & \multirow[t]{3}{*}{ Treatments } & \multicolumn{4}{|c|}{ Mycorrhizal parameters } \\
\hline & & \multicolumn{3}{|l|}{$\operatorname{MD}(\%)^{\mathrm{A}}$} & \multirow{2}{*}{$\begin{array}{l}\text { Active mycorrhizal } \\
\text { colonization }(\%)^{\mathrm{B}}\end{array}$} \\
\hline & & Shoot dry mass & $\mathrm{P}$ content & $\begin{array}{l}\text { Total chlorophyll } \\
(a+b)\end{array}$ & \\
\hline \multirow[t]{4}{*}{8} & $\mathrm{Gm}$ & $109 a^{*}$ & 106.9 a & $79.5 \mathrm{a}$ & $85.1 \mathrm{a}$ \\
\hline & Gd & $88 \mathrm{~b}$ & $63.5 \mathrm{~b}$ & $59.8 \mathrm{~b}$ & $68.2 \mathrm{~b}$ \\
\hline & Gig & $55 \mathrm{c}$ & $18.3 \mathrm{c}$ & $12.7 \mathrm{c}$ & $45.2 \mathrm{c}$ \\
\hline & $\operatorname{LSD}(5 \%)$ & 23.1 & 22.1 & 10.3 & 18.1 \\
\hline \multirow[t]{4}{*}{12} & $\mathrm{Gm}$ & $83.6 \mathrm{a}$ & $53.9 \mathrm{a}$ & $17.3 \mathrm{a}$ & $43.4 \mathrm{a}$ \\
\hline & Gd & $26.5 \mathrm{~b}$ & $40.6 \mathrm{~b}$ & $14.1 \mathrm{a}$ & $22.6 \mathrm{~b}$ \\
\hline & Gig & $13.9 \mathrm{~b}$ & $5.83 \mathrm{c}$ & $5.43 \mathrm{~b}$ & $16.8 \mathrm{~b}$ \\
\hline & $\operatorname{LSD}(5 \%)$ & 20.1 & 16.9 & 9.3 & 15.1 \\
\hline
\end{tabular}

Non-AMF Non-mycorrhizal, Gm Glomus mosseae, Gd Glomus deserticola, Gig Gigaspora gergaria

* Values in each column of each harvest followed by the same letter(s) are not significantly different at $P \leq 0.05$ (Duncan's multiple range test)

${ }^{\text {A }} \mathrm{MD}=\mathrm{M}-\mathrm{NM} / \mathrm{NM} \times 100$ where, $M$ is the parameter value of mycorrhizal plants and NM is the parameter value of non-mycorrhizal plants

B Active mycorrhizal colonization $=$ root colonized by active arbuscules (SDH)/total arbuscules (TB)

partially due to the prevention of $\mathrm{Na}^{+}$absorption and translocation to shoot tissues. Plaut and Grieve (1988) found that increased $\mathrm{P}$ in mycorrhizal plants resulted in decreased $\mathrm{Na}^{+}$, which was indirectly related to $\mathrm{Ca}^{2+}$ and $\mathrm{Mg}^{2+}$ uptake when compared to the non-mycorrhizal ones. Moreover, Ojala et al. (1983) found that AM-inoculated onion plants had higher concentrations of $\mathrm{K}^{+}$in shoots and bulbs under salt stress conditions. Furthermore, AM which could be beneficial by maintaining a high $\mathrm{K} / \mathrm{Na}$ ratio and by influencing the ionic balance in the cytoplasm (Founoune et al. 2002) or $\mathrm{Na}$ efflux from the plants (Allen and Cunningham 1983). Cantrell and Linderman (2001) suggested that AM fungi improved $\mathrm{P}$ nutrition of plants grown under salinity stress and reduced the negative effects of $\mathrm{Na}$ by maintaining vacuolar membrane integrity, and thus preventing those ions from interfering with growth metabolic pathways. It has been mentioned that maintaining the membrane integrity can facilitate the compartmentalization 
within vacuoles and selective ion intake (Rinaldalli and Mancuso 1996; Sheng et al. 2009).

Chlorophyll contents have been suggested as one of the parameters of salt tolerance in plants (Sirivastava et al. 1998), and carotenoids are responsible for quenching of singlet oxygen (Knox and Dodge 1985); hence, their levels may determine the relative salt tolerance of the plants. The present study demonstrates that the photosynthetic pigments in leaves of mycorrhizal wheat plants were significantly higher than those in non-mycorrhizal plants. The leaves of non-mycorrhizal plants were more chlorotic than those of mycorrhizal plants. This suggests that salt interferes with chlorophyll synthesis more in non-mycorrhizal than in mycorrhizal plants. Under salinity stress, there could be several reasons for low chlorophyll content in plant tissues. One explanation might be that $\mathrm{Na}$ has an antagonistic effect on Mg absorption (Daei et al. 2009). In the present investigation, a higher concentration of $\mathrm{Mg}$ was observed in wheat plants as a result of AM fungal infection. This suggests that mycorrhizal fungi reduce the antagonistic effect of $\mathrm{Na}$. It has been reported that mycorrhizal fungi are effective in absorption of $\mathrm{Mg}$, and suppression of $\mathrm{Na}$ under salt stress conditions (Giri and Mukerji 2004; Ibrahim et al. 2011).

In saline soil, acid and alkaline phosphatase activities were significantly higher in mycorrhizal than in nonmycorrhizal wheat root extracts. Such increases in those activities were related to the degree of active mycorrhizal infection of each fungal species. These data are in agreement with those found by Gianinazzi-Pearson and Gianinazzi (1978) and Ezawa and Yoshida (1994) who stated that mycorrhizal-specific phosphatase (MSPase) was detected only in the mycorrhizal root extract, and there was a strong evidence that it was of fungal origin. The close relation between mycorrhizal growth responses and the active arbuscular phase of the infection supports the hypothesis that the phosphatase enzyme is somehow involved in the assimilation of phosphorus by arbuscular mycorrhizal fungi (Gianinazzi et al. 1982; Abdel-Fattah 2001).

AM-inoculated wheat plants had higher contents of proline in leaves and protein in roots than non-mycorrhizal plants grown in saline soil. The observed increase in proline and protein contents in salt grown mycorrhizal plants is in a good conformity with the results of other researchers (Goudarzi and Pakniyat 2009; Ibrahim et al. 2011). This increment in proline could be due to the induction of proline biosynthesis enzymes and/or to the reduction of oxidation to glutamate (Stewart 1981). Several roles have been attributed to this supraoptimal level of proline; for instance, osmoregulation (Delauney and Verma 1993) and detoxification of free radicals (Kaul et al. 2008). Higher protein concentration could be due to the higher efficiency of the osmotic regulation mechanism in wheat plants which in turn prevents protein reduction under salt stress (Flowers and Yeo 1995; Kumar et al. 2010), and induces the synthesis of osmotin like protein structure (Amini and Ehsanpour 2005). This protein increment lead to membrane stabilization, and helps plants to grow and develop under saline conditions (Goudarzi and Pakniyat 2009).

The present investigation showed that arbuscular mycorrhizal inoculation (particularly G. mosseae) significantly alleviated the harmful effects of salt stress on wheat plants grown in saline soil via, reducing Na uptake, as well as increasing of $\mathrm{P}, \mathrm{N}, \mathrm{K}$ and $\mathrm{Mg}$ contents, and stimulating photosynthetic pigments and some metabolic contents of the wheat plants. Moreover, the rate of shoot growth, nutrient contents and some metabolic activities of wheat plants in responding to mycorrhizal inoculation was not directly related to the level of the mycorrhizal infection stained by trypan blue (non-vital stain). SDH activity (vital stain) technique may be potential and necessary for estimating the mycorrhizal infection.

Acknowledgments Authors wish to thank College of Food and Agricultural Research Center and Deanship of Scientific Research, King Saud University, Saudi Arabia for supporting this work.

Open Access This article is distributed under the terms of the Creative Commons Attribution Noncommercial License which permits any noncommercial use, distribution, and reproduction in any medium, provided the original author(s) and source are credited.

\section{References}

Abdel-Fattah GM (1991) Some physiological and ecological studies on vesicular-arbuscular (VA) mycorrhizal fungi. Ph.D thesis, Mansoura University, Egypt, p 350

Abdel-Fattah GM (2001) Measurement of the viability of arbuscularmycorrhizal fungi using three different stains; relation to growth and metabolic activities of soybean plants. Microbiol Res 156:359-367

Abdel-Fattah GM, Abo-Hamed SA, Mohamed ZA (1996) The role of VA-mycorrhizal fungus (Glomus mosseae) and kinetin in alleviation of salinity stress in Pisum sativum plants. 1st International Conference on Fungi. Hopes \& Challenges, Cairo, 2-5 Sept, pp 67-81

Abdel-Fattah GM, Migahed FF, Ibrahim AH (2002) Interactive effects of endomycorrhizal fungus Glomus etunicatum and phosphorus fertilization on growth and metabolic activities of broad bean plants under drought stress conditions. Pak J Biol Sci 5:835-841

Abdel-Ghani AH (2009) Response of wheat varieties from semi-arid regions of Jordan to salt stress, J. Agron Crop Sci 195:55-65

Abo-Ghalia HH, Khalafallah AA (2008) Responses of wheat plants associated with arbuscular mycorrhizal fungi to short-term water stress followed by recovery three growth stages. J Appl Sci Res 4:570-580

Agwa HE, Abdel-Fattah GM (2001) Arbuscular mycorrhizal fungi (Glomales) in Egypt. II- An ecological view of some saline affected plants in the deltaic Mediterranean coastal land. Acta Botanica Hungarica 44:10-17 
Al-Karaki GN (2006) Nursery inoculation of tomato with arbuscular mycorrhizal fungi and subsequent performance under irrigation with saline water. Sci Hortic 109:1-7

Al-Karaki GN, Hammad R, Rusan M (2001) Response of two tomato cultivars differing in salt tolerance to inoculation with mycorrhizal fungi under salt stress. Mycorrhiza 11:43-47

Allen SE (1989) Chemical analysis of ecological materials, 2nd edn. Blackwell Sci Pub, Osney

Allen EB, Cunningham GL (1983) Effects of vesicular mycorrhiza on Distichlis spicata under three salinity levels. New Phytol 93:227-236

Amini F, Ehsanpour A (2005) Soluble proteins, proline, carbohydrates and $\mathrm{Na}^{+} / \mathrm{K}^{+}$changes in two tomato (Lycopersicon esculentum Mill.) cultivars under in vitro salt stress. Am J Biochem Biotech 1:204-208

Apse MP, Dharon GS, Snedden WA, Bumerold E (1999) Salt tolerance conferred by overexpression of a vacuolar $\mathrm{Na}^{+} / \mathrm{H}^{+}$ antiport in Arabidopsis. Science 258:1256-1258

Arnon DJ (1949) Copper enzyme in isolated chloroplasts polyphenol oxidase in Beta vulgaris. Plant Physiol 24:1-15

Asrar AA, Elhindi KM (2011) Alleviation of drought stress of marigold (Tagetes erecta) plants by using arbuscular mycorrhizal fungi. Saudi J Biol Sci 19:38-46

Azcon R, Atrash F (1997) Influence of arbuscular mycorrhizae and phosphorus fertilization on growth, nodulation and $\mathrm{N}_{2}$ fixation $\left({ }^{15} \mathrm{~N}\right)$ in medicago sativa at four salinity levels. Biol Fertil Soils 24:81-86

Bradford MM (1976) A rapid and sensitive method for the quantification of microgram quantities of protein utilizing the principle of protein-dye binding. Annal Biochem 72:248-254

Cantrell IC, Linderman RG (2001) Preinoculation of lettuce and onion with AM mycorrhizal fungi reduces deleterious effects of soil salinity. Plant Soil 233:269-281

Daei G, Ardekani MR, Rejali F, Teimuri S, Miransari M (2009) Alleviation of salinity stress on wheat yield, yield components, and nutrient uptake using arbuscular mycorrhizal fungi under field conditions. J Plant Physiol 166:617-625

Delauney AJ, Verma DP (1993) Proline biosynthesis and osmoregulation in plants. Plant $\mathrm{J}$ 4:215-223

Duke ER, Johnson CR, Koch KE (1986) Accumulation of phosphorus, dry matter and betaine during $\mathrm{NaCl}$ stress of split $=$ root citrus seedlings colonized with vesicular arbuscular mycorrhizal fungi on zero, one or two halves. New Phytol 104:583-590

Evelin H, Kapoor R, Giri B (2009) Arbuscular mycorrhizal fungi in alleviation of salt stress: a review. Ann Bot 104:1263-1280

Ezawa T, Yoshida T (1994) Characterization of phosphatase in marigold roots infected with vesicular-arbuscular mycorrhizal fungi, Glomus spp. and Gigaspora spp. Plant Soil 176:57-63

Flowers TJ, Yeo AR (1995) Breeding for salinity resistance in crop plants. Aust J Plant Physiol 22:875-884

Founoune H, Duponnois R, Ba AM, El-Bouami F (2002) Influence of the dual arbuscular endomycorrhizal/ectomycorrhizal symbiosis on the growth of Acacia holosericea (A. Cunn. Ex G. Don) in glasshouse conditions. Ann For Sci 59:93-98

Gerdemann JW, Nicolson TH (1963) Spores of mycorrhizal Endogone species extracted from soil by wet-sieving and decanting. Trans Br Mycol Soc 46:235-244

Gianinazzi S, Gianinazzi-Pearson V, Trouvelot A (1982) Mycorrhizae, an integral part of plants: biology and perspectives for their use. INRA-Press, Paris, p 397

Gianinazzi S, Gianinazzi-Pearson V, Tisserant B, Lemoine MC (1992) Protein activities as potential markers of functional endomycorrhizas. New Phytol 82:127-132

Gianinazzi-Pearson V, Gianinazzi S (1976) Enzymatic studies on the metabolism of vesicular-arbuscular mycorrhizal. I. Effect of mycorrhizal formation and phosphorus nutrition on soluble phosphatase activities in onion roots. Physiol Veg 14:833-841

Gianinazzi-Pearson V, Gianinazzi S (1978) Enzymatic studies on the metabolism of vesicular-arbuscular mycorrhizal. II. Soluble alkaline phosphatase specific to mycorrhizal infection in onion roots. Physiol Plant Pathol 12:45-53

Giri B, Mukerji KG (2004) Mycorrhizal inoculant alleviates salt stressing Sesbania aegyptiaca and Sesbania grandiflora under field conditions: evidence for reduced sodium and improved magnesium uptake. Mycorrhiza 14:307-312

Goudarzi M, Pakniyat H (2009) Salinity causes increase in proline and protein contents and peroxidase activity in wheat cultivars. J Appl Sci 9:348-354

Graham JH, Syvertsen JP (1985) Host determination of mycorrhizal dependency of citrus rootstock seedlings. New Phytol 101:667-676

Hamel E, Fyles H, Smith DL (1990) Measurement of development of endomycorrhizal mycelium using three different stains. New Phytol 155:297-302

Harborne JB (1984) Photochemical methods. A guide to modern techniques of plant analysis. Chapman and hall, London

Harley JL, Smith SE (1983) Mycorrhizal symbiosis. Academic Press, London, p 483

Ibrahim AH, Abdel-Fattah GM, Eman FM, Abd El_Aziz MH, Shohr AE (2011) Arbuscular mycorrhizal fungi and spermine alleviate the adverse effects of salinity stress on electrolyte leakage and productivity of wheat plants. Phyton (in press)

Jackson NE (1973) Soil chemical analysis. Printice Hall Inc, Englewood Cliffs, p 498

Juniper S, Abbott L (1993) Vesicular-arbuscular mycorrhizas and soil salinity. Mycorrhiza 4:45-57

Kaul S, Sharma SS, Mehta IK (2008) Free radical scavenging potential of L-proline evidence from in vitro assays. Amino Acids 34:315-320

Knox JP, Dodge AO (1985) Singlet oxygen and plants. Phytochemistry 24:889-896

Knudsen D, Peterson GA, Pratt PF (1982) Lithium, sodium and potassium. In: Page AL (ed) Methods of soil analysis: part 2. Chemical and microbiological properties. ASA Monograph Number 9, pp 225-246

Kough JL, Gianinazzi-Pearson V, Gianinazzi S (1987) Depressed metabolic activity of vesicular-arbuscular mycorrhizal fungi after fungicide application. New Phytol 106:707-715

Kumar A, Sharma S, Mishra S (2010) Influence of arbuscular mycorrhizal (AM) fungi and salinity on seedling growth, solute accumulation and mycorrhizal dependency of Jatropha curcas L. J Plant Growth Regul 29:297-306

Mankarios AT, Abdel-Fattah GM (1994) Ecology of VA-mycorrhizal in some Egyptian soils. Egypt J Bot 34:135-152

Marschner H (1995) Mineral nutrition of higher plants, 2nd edn. Academic Press, New York

Munns R, James RA, lauchli A (2006) Approaches to increasing the salt tolerance of wheat and other cereals. J Exp Botany 57:1025-1043

Nelson DW, Sommers LE (1973) Determination of total nitrogen in plant material. Agron J 65:109-112

Ojala JC, Jarrel WM, Menge JA, Johnson ELV (1983) Influence of mycorrhizal fungi on the mineral nutrition and yield of onion in saline soil. Agron J 75:255-259

Olsen SR, Cole CV, Watanabe FS, Dean LA (1954) Estimation of available phosphorus in soils by extraction with sodium biocarbonate. USDA Circular 939

Paradi I, Bratek Z, Berecz K, Halasz K (2002) Influence of arbuscular mycorrhiza, P limitation and Cd-stress on polyamine contents of plants. Acta Biologica Szegediensis 46:59-60 
Phillips JM, Hayman DS (1970) Improved procedures for clearing roots and staining parasitic and vesicular-arbuscular mycorrhizal fungi for rapid assessment of infection. Trans $\mathrm{Br}$ Mycol Soc 55:158-161

Plaut Z, Grieve CM (1988) photosynthesis of salt stressed maize as influenced by $\mathrm{Ca}: \mathrm{Na}$ ratios in the nutrient solution. Plant Soil 105:283-286

Pond EC, Menge JA, Jarrell WM (1984) Improved growth of tomato in salinized soil by vesicular arbuscular mycorrhizal fungi collected from saline sites. Mycologia 76:74-84

Poss JA, Pond E, Meneg JA, Jarrell WM (1985) Effect of salinity on mycorrhizal onion and tomato in soil with and without additional phosphate. Plant Soil 88:307-322

Rinaldalli E, Mancuso S (1996) Response of young mycorrhizal and non-mycorrhizal plants of olive tree (Olea europaea L.) to saline conditions. I. Short-term electrophysiological and long-term vegetative salt effects. Adv Hortic Sci 10:126-134

Roychoudhury A, Basu S, Sengupta DN (2010) Amelioration of salinity stress by exogenously applied spermidine or spermine in three varieties of indica rice differing in their level of salt tolerance. J Plant Physiol 18:12-17

Ruiz-Lozano M, Azcon R (2000) Symbiotic efficiency and infectivity of an autochthonous arbuscular mycorrhizal Glomus sp. from saline soils and Glomus deserticola under salinity. Mycorrhiza 10:137-143

Sadasivam S, Manickam A (1996) Biochemical methods, 2nd edn edn. New age International Limited Publishers, New Delhi, p 291
Sairam RK, Rao KV, Srivastava GC (2002) Differential response of wheat genotypes to long-term salinity stress in relation to oxidative stress, antioxidant activity and osmolyte concentration. Plant Sci 163:1037-1046

Sheng M, Tang M, Chen H, Yang B, Zhang F, Huang Y (2009) Influence of arbuscular mycorrhizae on the root system of maize plants under salt stress. Can J Microbiol 55:879-886

Shih SF, Synder GH (1984) Leaf area index and dry biomass of taro. Agron J 76:750-753

Sirivastava TP, Gupta SC, Lal P, Muralia N, Kumar N (1998) Effect of salt stress on physiological and biochemical parameters of wheat. Ann Arid Zone 27:197-204

Smith SE, Dickson S, Morris C, Smith FA (1990) Transfer of phosphate from fungus to plant in VA mycorrhizas: Calculation of the area of symbiotic interface and of fluxes of $\mathrm{P}$ from two different fungi to Allium porrum L. New Phytol 127:93-99

Stewart CR (1981) Proline accumulation: biochemical aspects. In: Paleg LG, Aspinall D (eds) Physiology and biochemistry of drought resistance in plants. Academic Press, Sydney, pp 243-259

Trouvelot A, Kough J, Gianinazzi-Pearson V (1986) Evaluation of VA infection levels in root systems. Research for estimation methods having a functional significance. In: Gianinazzi-Pearson V, Gianinazzi S (eds) Physiological and genetical aspects of Mycorrhizae. INRA Press, Paris, pp 217-221

Wu QS, Zon YN, Liu W, Ye XE, Zai HE, Zhao LJ (2010) Alleviation of salt stress in citrus seedlings inoculated with mycorrhiza: changes in leaf antioxidant defense systems. Plant Soil Environ $56: 470-475$ 